УДК: 378.016:159.9

DOI: 10.26697/ijes.2019.4.19

\section{Професійна мобільність майбутнього психолога: сутність поняття}

Аспірант Зубко В. С.

${ }^{1}$ Вінницький державний педагогічний університет імені Михайла Коцююбинського, Україна

\begin{abstract}
Резюме
Вступ:

Сучасний психолог повинен володіти не тільки професійними знаннями, а й вміти гнучко пристосовуватися до різних ситуацій, що часто змінюються, в професійній діяльності. Відповідно, психологу необхідно бути готовим до того, що отриманого в педагогічному університеті початкового освіти буде недостатньо і доведеться протягом життя постійно навчатися самостійно i перенавчатися, удосконалюючи свою професійну кваліфікацію. Реальність сьогодення засвідчує, що без наявності добре розвиненої готовності до професійної мобільності майбутній психолог не $\epsilon$ конкурентоспроможним на ринку послуг. Перспективи подальшого кар'єрного і професійного зростання для такого працівника $\epsilon$ досить обмеженими. Здатність до саморозвитку $є$ основою розвитку готовності до професійної мобільності майбутнього психолога.
\end{abstract}

\section{Результати:}

Науковці по різному визначають сутність поняття “професійна мобільність". Так, наприклад, І. Хом’юк професійну мобільність майбутніх фахівців визначила як здатність особи швидко переключатися на суміжний вид діяльності в межах своєї спеціальності, що в свою чергу вимагає: постійно підвищувати свою освіту і кваліфікацію; швидко освоювати технічні засоби, технічні процеси; уміння швидко орієнтуватися в ситуації; здатності швидко реагувати на соціально-економічні зміни завдяки професійній компетентності. На думку науковця, професійна мобільність майбутнього фахівця визначається у: здатності швидко переключатися 3 одного виду діяльності на інший; готовності визначати оптимальні умови виконання технологічних операцій; спроможності вивчити та аналізувати наукову літературу, періодичні видання, Internet та досвід щодо досліджуваного процесу або об'єкта дослідження, застосовуючи сучасні методики пошуку інформації. Безперечно, основні характеристики професійної мобільності, визначені науковцем, можуть стосуватися і майбутніх психологів.

Окремі науковці професійну мобільність розуміють як здатність швидко адаптуватися у різних сферах діяльності, що базується на прагненні до самореалізації та самовдосконалення. На нашу думку, готовність майбутніх психологів до професійної мобільності можна вважати складовою їхньої професійної компетентності.
Також професійну мобільність майбутнього фахівця визначають як складне інтегративне утворення в структурі особистості, що поєднує особистісні й професійні якості, при цьому важливими є мотиваційна спрямованість, потреба у професійній самореалізації, готовність до нового та інноваційних змін.

У зв'язку 3 цим сучасний психолог повинен володіти не тільки професійними знаннями, а й вміти гнучко пристосовуватися до різних ситуацій, що часто змінюються, в професійній діяльності. Відповідно психологу необхідно бути готовим до того, що отриманого в педагогічному університеті початкового освіти буде недостатньо і доведеться протягом життя постійно навчатися самостійно i перенавчатися, удосконалюючи свою професійну кваліфікацію. Реальність сьогодення засвідчує, що без наявності добре розвиненої готовності до професійної мобільності майбутній психолог не є конкурентоспроможним на ринку послуг. Перспективи подальшого кар'єрного i професійного зростання для такого працівника $є$ досить обмеженими. Здатність до саморозвитку $є$ основою розвитку готовності до професійної мобільності майбутнього психолога.

\begin{abstract}
Висновки:
Таким чином, щодо визначення своєрідності процесу підготовки до професійної мобільності майбутнього психолога, то вона ще не виступала предметом окремого наукового пошуку.

Важливо вивчити й врахувати зарубіжний досвід щодо досліджуваної проблеми, оскільки вивчення досвіду країн Свросоюзу щодо модернізації освіти в контексті професійної мобільності в умовах європейської інтеграції становить безсумнівний інтерес для української педагогічної спільноти.

Узагальнення викладеного дає змогу визначити "професійну мобільність" як інтегративну особистісну якість, що виявляється у: здатності успішно переходити від одного виду діяльності до іншого; володінні високим рівнем узагальнених професійних знань, досвідом їх удосконалення та самостійного оволодіння; готовності до оперативного відбору і реалізації оптимальних способів виконання завдань у галузі діяльності.
\end{abstract}

Інформація про автора:

Зубко Віта Сергіївна - аспірант, Вінницький державний педагогічний університет імені Михайла Коцюбинського, Вінниця, Україна.

Наукові інтереси: професійна мобільність майбутнього психолога; https://orcid.org/0000-00031681-401X.

Автор-Кореспондент:

Зубко Віта Сергіївна

Email Автора-Кореспондента:

vitazubko7@gmail.com 